\title{
ГЕНЕЗА УНІВЕРСИТЕТСЬКОЇ АВТОНОМІЇ Й АКАДЕМІЧНОЇ СВОБОДИ
}

\section{Таяновський В. О.}

здобувач третього (освітньо-наукового) рівня вищої освіти, Київський університет імені Бориса Грінченка, м. Київ, Україна

Описано сутність та правове підгрунтя становлення університетської автономії. Визначено поняття, генезу та соціально-правову природу академічної свободи, досліджено ї̈ основні етапи розвитку. Зроблено висновок, щчо найбільш суттєвими викликами для академічної свободи сьогодні є: масовізачія освіти; менеджеріалізація університетських структур; комерціалізація науки й освіти.

Ключові слова: університет, університетська автономія, академічна свобода, освіта, ринок освітніх послуг.

The essence and legal basis for the formation of university autonomy described. The concept, genesis, social and legal nature of academic freedom are defined, its main stages of development are investigated. It is concluded that the most significant challenges for academic freedom today are: massification of education; managerialization of university structures; commercialization of science and education.

Key words: university, university autonomy, academic freedom, education, market of educational services.

Україна, визначаючи орієнтир входження в освітній простір Європи, здійснює у контексті європейських вимог модернізацію освітньої діяльності. Одним із важливих напрямів є забезпечення надання можливості закладам вищої освіти діяти відповідно керівних принципів академічної свободи. Участь у Болонському процесі передбачає підвищення відповідальності закладів вищої освіти перед суспільством 3 одночасним наданням їм більших прав і свобод та зменшенням участі держави в життєдіяльності академічної спільноти.

Тож актуальність статті зумовлена теоретичною і практичною значущістю широкого кола проблемних питань щодо розуміння змісту та генези академічної свободи, а також супутніх питань університетської автономії та їі нормативно-правового регулювання.

Академічна свобода тісно пов'язана 3 автономією закладу освіти, яка символізує його самостійність, незалежність у процесі реалізації навчального процесу, науковій, фінансовій, господарській діяльності, 
підборі кадрів тощо. Академічна свобода - це свобода, яку надає суспільство членам академічної спільноти для того, щоб зробити можливим виконання, покладених на них завдань.

Автономія закладів вищої освіти виникла разом із появою університетів. Як відомо, перші ранні університети Свропи з'явилися в Болоньї (1158), Оксфорді (1167), Парижі (1200), Кембриджі (1209), Неаполі (1224), Лісабоні (1290), Празі (1347-1348), Флоренції (1349), Гейдельберзі (1385), Турині (1405), Лейпцигу (1409) та інших містах світу. Як зазначають сучасні дослідники, перші університети користувалися переважно правовою, політичною, економічною автономією (що було так званим привілеєм, наданим владою), але аж ніяк не академічними свободами [1].

Автономія в освітній діяльності означає, що університет сам вирішує, які знання передавати студентам і які при цьому використовувати методики. Адміністративна автономія - можливість самостійно планувати та контролювати прийом студентів, викладацький та дослідницький персонал, розробляти власні навчальні програми, присвоювати наукові ступені та встановлювати відносини 3 іншими ЗВО в країні і за кордоном. Університет користується фінансовою автономією, працюючи з відповідним контролем з боку державних органів. Проте недопустимо, щоб автономія мала суперечності з визначеними для університету формами звітності. У цьому аспекті автономію доцільно вважати відносною категорією, а академічні свободи - абсолютною, оскільки останні тісно пов'язані з ефективністю, результативністю та продуктивністю діяльності університету [2, с. 342].

Нове озвучення концепції академічних прав і свобод в історії університетської освіти датується кінцем XVII ст. і пов'язане з іменами англійських філософів Джона Локка і Томаса Хобса. Їхні погляди щодо необхідності відмови на обмеження в царині наукових досліджень і дотримання загальних підходів у навчанні, вільному від всяких застережень, проклали шлях до академічної свободи у сучасному розумінні.

У протилежному напрямі стали розвиватись університети Франції. Факультети тут перетворились на самостійні навчальні заклади, відокремившись від закладів, що безпосередньо займались науковими дослідженнями, а викладачі були занесені до реєстру державних службовців. До середини XIX століття у французьких університетах запере- 
чувалась не тільки академічна свобода, але й деякі громадянські свободи науково-педагогічних працівників.

3 часом вплив держави на університетське життя посилюється, не зважаючи на протидію з боку академічної спільноти. Зазначений процес став сприятливим для змін інституційних форм управління й організації університетів. Найбільш стійкими виявилися найстаріші університети Європи, такі як Оксфордський і Кембриджський, у яких збереглася автономія й академічна свобода як головні надбання. Цю ж традицію перейняли елітні приватні американські університети, такі, як Гарвардський чи Стенфордський.

Практичне втілення засад академічної свободи у XIX ст. міцно закріпив Берлінський університет, який був заснований 1810 року і став моделлю німецького університету на наступні два століття. Знаменитий філолог, історик і філософ Вільгельм фон Гумбольдт, який був призначений відповідальним за відновлення німецьких університетів, сформулював уявлення про належну організацію університету і відобразив їх у формі свободи викладання (Lehrfreiheit), свободи навчання (Lernfreiheit) та єдності навчання і наукових досліджень (Einheit von Forschung and Lehre). Чимало $з$ поглядів Гумбольдта вважалися утопічними, згодом він був відсторонений від роботи, однак саме ідеї цього вченого сформували основу не тільки сучасного дослідницького університету, але й сучасного розуміння академічної свободи.

Невід'ємною частиною концепції Гумбольдта були свобода дій і вільна конкуренція між професорами, які, хоча і перебували на державній службі, проте могли вільно обирати університет серед численних і незалежних у той час німецьких князівств. Їхнє ім'я і престиж, а відповідно - й можливість знайти роботу, залежали тільки від рівня досліджень і спеціалізації в тій чи іншій науковій дисципліні. Викладач міг автономно визначати, на якій методологічній базі, в якому напрямі та на якому рівні він викладатиме. 3 боку студента передбачалася передусім свобода вибору дисциплін, семінарів та автономне формування свого навчального плану. Відповідно до гумбольдтівської моделі студент міг обирати семінари, які він хотів відвідувати, і навіть до певного часу поєднувати у своєму навчальному плані абсолютно різні дисципліни: право та філософію, біологію та літературу. Саме завдяки доктрині „Lehr- und Lernfreiheit” до загального вжитку увійшло поняття академічної свободи - свободи навчання і викладання. 
Німецькі філософи I. Фіхте, В. Шеллінг, Ф. Шлейермахер розробили нову концепцію університетської освіти, яка грунтувалась на античному ідеалі виховання й навчання людини, яка прагнула до повного розкриття своєї особистості. 3 приводу цього I. Фіхте зазначав, що університет повинен стати «ідеальним союзом вільних думок». Відповідно до цієї концепції, ідея університету базувалась на таких принципах: відносна незалежність; сутність університету у принципі академічної свободи; єдність наукових досліджень та навчання; політичне значення ідей освіти.

В зазначеному аспекті досліджуваної проблеми привертає увагу те, що, не дивлячись на те, що в XIX столітті німецький університет визначався як державний заклад, що фінансується і керується державними органами влади, він зберігав певний рівень самостійності, i, за переконанням дослідників, користувався такою свободою, якої не мала жодна установа Німеччини означеного періоду. Так, факультети німецьких університетів обирали своїх деканів, розподіляли стипендії, організовували іспити, рекомендували міністерству кандидатури на заміщення вакантних посад на кафедрах тощо.

Натомість у французьких університетах подібних свобод не було, там панувала жорстка дисципліна, адміністрація контролювала всі аспекти діяльності - від розкладу і програми занять до присудження ступенів, затвердження офіційної точки зору на кожне скільки-небудь значуще питання і навіть зовнішній вигляд викладачів (наприклад, у 1852 р. їм забороняли відпускати бороду). Престиж викладача відображав не його особисті заслуги, а залежав від репутації закінченого ним закладу освіти. Однак у другій половині XIX ст. німецька модель університету почала здійснювати вплив і на порядки у французьких університетах.

Певною віхою в науковому осмисленні академічної свободи стали праці й активна громадська діяльність американських філософів Дж. Дьюї та А. Лавджоя, ідейних і організаційних натхненників створення Американської асоціації університетських професорів і розробки Декларації принципів академічної свободи [3].

У другій половині ХІХ ст. остаточно формується образ сучасного університету. Саме в цей період університети повною мірою відроджують свою функцію щодо виробництва знань, а ідея університету, орієнтованого на дослідження, стає превалюючою. 


\section{Список використаної літератури:}

1. Ківалов С. В. Університетська автономія: генеза ідеї та історичний досвід iii впровадження. Актуальні проблеми політики. 2015. Вип. 56. С. 3-11.

2. Садовничий В. А. Университетское образование: приглашение к размышлению. М. : Издательство Московского университета, 1995. 352 с.

3. Хлуднева С. В. Джон Дьюи и Артур Лавджой: борьба за академические свободы. Вопросы философии. 2004. № 12. С. 164-172.

4. Worldwide status of higher education institutions [Електр. peсурс]. - Режим доступу: https://www.who.int > monitoring > inputs > WHED

5. Becher T. The state and the university curriculum in Britain. European Journal of education. 1994. Vol. 29. № 3. P. 231-245.

6. Coghlan E. R. University autonomy: The' 80 s and after. Higher education quarterly. 1994. Vol. 48. № 2. P. 86-117.

7. Kogan M. Assessment and productive research. Higher education quarterly. 1994. Vol. 48. № 1. P. 57-67.

8. Russel C. Academic freedom: a reply. Minerva. 1994. Vol. 32. № 3. P. 334- 